\title{
Eat your veg
}

\section{With fish farming on the rise, researchers are seeking ways to make aquaculture more sustainable. One solution may mean turning carnivorous fish into vegetarians. Kendall Powell gets a taste of the future.}

$\mathrm{G}$ lobal aquaculture is on the rise, growing more than $5 \%$ per year over the past decade. That might sound like good news for the world's food supply, but there's a hidden cost behind some of the farmed fish on supermarket shelves. Many, including the popular salmon, trout and cod, are fed on wild fish. Lots of wild fish. Today, about 11 million tonnes of fish $-12 \%$ of the total haul from seas and rivers - are caught each year just to feed farmed fish ${ }^{1,2}$. It takes 2 to $5 \mathrm{~kg}$ of wild fish just to produce $1 \mathrm{~kg}$ of a farmed fish such as salmon ${ }^{2}$.

Over the past few decades, researchers have begun to think that one way to make aquaculture more sustainable is to change the diets of some of our farmed fish - to turn carnivores into vegetarians ${ }^{3}$. It's a solution that carries its own challenges, but in the face of declining wild stocks and a booming aquaculture industry, many fish farmers and conservationists agree that if we are to continue farming carnivorous fish, this is the way to go.

The world's most-farmed fish, carp and tilapia, are predominantly vegetarian, and so can easily be farmed on a diet of plants. In Asia, where currently about $90 \%$ of the world's aquaculture takes place, these fish are big business. But in the western world, where carp is often considered to be bony and tilapia is a relatively new and unfamiliar product, neither has so far managed to out-compete meaty salmon steaks on restaurant menus.

Lagging just behind the production of farmed tilapia are salmon and trout - both of which are natural carnivores. Although the number of these fish being farmed is onetenth that of farmed carp, it is a growth area, and farming of other carnivorous fish, such as cod, halibut, sea-bass, sea bream and tuna, is also increasing. Only 600 tonnes of farmed Atlantic cod were produced worldwide in 2001, but Norway has now started commercial production, and Hans Abrahamsen, managing director of aquafeed producer Skretting in Stavanger, Norway, estimates that the country will produce up to 30,000 tonnes per year by 2008 . Altogether, the production of carnivorous fish is expected to double by 2010 (ref.2).

This will soon pose a huge problem. Farmed fish are fed on a diet that leans heavily on fish oil and fishmeal - a protein-rich powder of ground-up, cheap fish such as sardines, anchovies and eels - as a source of vital proteins and nutrients. A simple calculation shows that the current haul of fish oil and fishmeal will soon be outstripped by the needs of global aquaculture. If the number of fish farmed continues to grow at its current rate, and if the supply of oil and meal stays the same — asithas for the past decade — then demand will outstrip supply of oil by 2010 (ref. 4). If those projections are extended, fishmeal looks set to face the same problem by 2050 .

\section{Feeding frenzy}

In response, feed companies are seeking different sources of protein and, in particular, oil. The feed fisheries have turned to larger fish, such as mackerel, herring, blue whiting and Norway pout, causing further pressures on natural stocks. Some companies are also going after krill - tiny crustaceans found predominantly in Antarctica. "That's going to the base of the food chain, which has all kinds of ramifications for the oceans' web of life," says Bill Mott, director of the information centre SeaWeb Aquaculture Clearinghouse in Providence, Rhode Island.

There are also economic reasons to switch

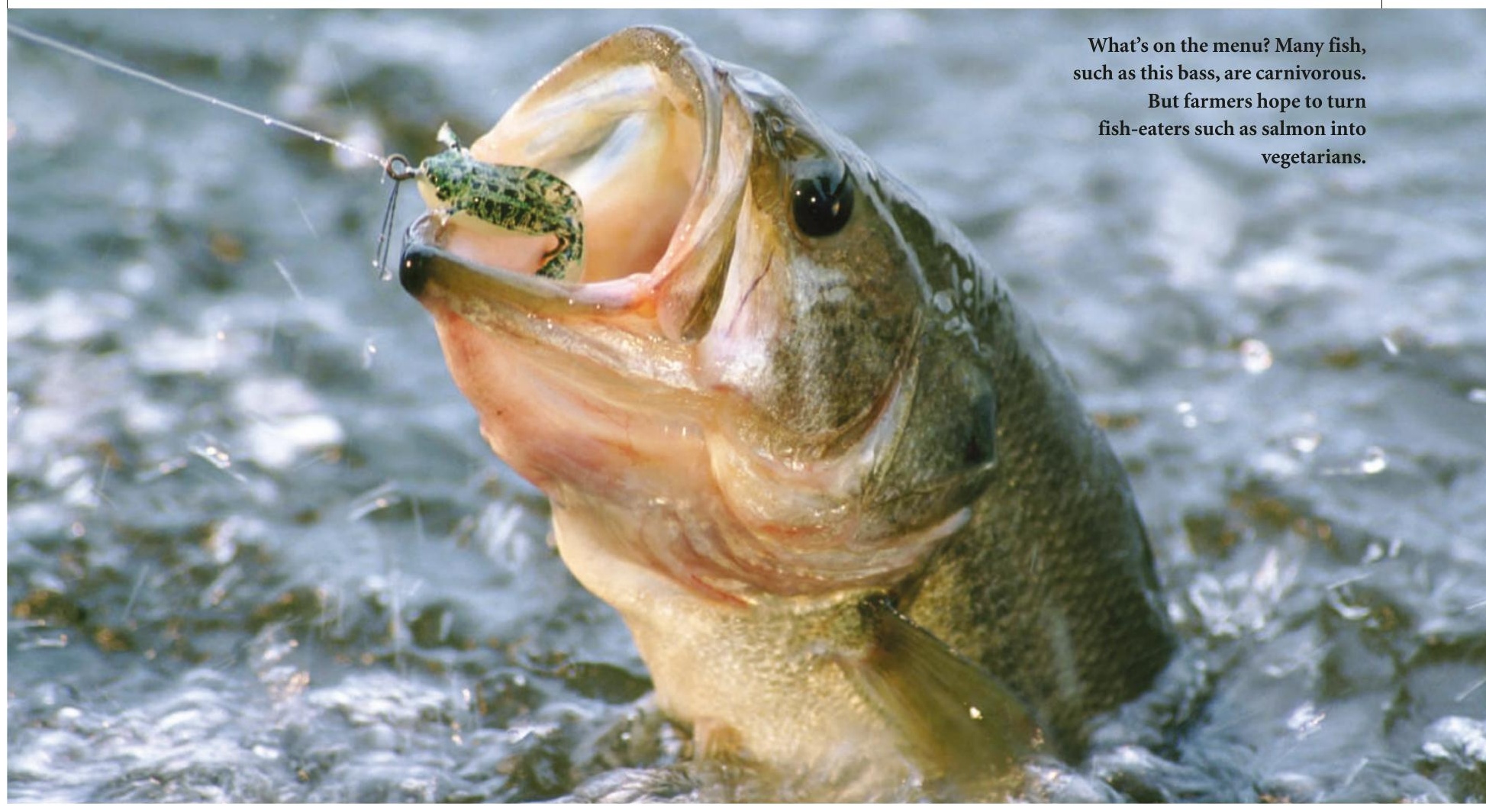


diets away from fishmeal and oil. Feed makes up three-quarters of fish farmers' total running costs, and the price of oil will only go up as demand rises. "For fish-feed producers today, it's not a question, we have to use alternatives," says Jørgen Holm, a fish nutritionist at the feed company BioMar in Brande, Denmark.

In theory, this shouldn't be difficult. Trond Storebakken, director of the Aquaculture Protein Centre in Ås, near Oslo, Norway — an institute devoted to this problem — says that moving a carnivorous fish onto a vegetarian diet is similar to someone deciding to become a vegan. "A person eating only boiled soya beans and raw cabbage would get bone demineralization and goitre in a few months," he says. "But if you know the requirements then you can eat the right things."

\section{Hard to swallow}

Today, the options for vegetarian fish diets include soya beans, corn, rapeseed, sunflower seeds, flaxseeds and wheat gluten. Some farmed salmon already get up to half of their protein or oils from such ingredients, without their health or growth rates suffering ${ }^{5}$. But attempts to push diets past the half-vegetarian point tend to cause serious digestion problems - fish suffer from irritated lower intestines and a depressed immune system, and lose their ability to absorb key minerals such as zinc and iron. So far, the only way to solve these problems costs a lot of money. "I could give you a simple prescription for a $100 \%$ vegetarian diet for carnivorous fish that works, but it would be extremely expensive," says Storebakken.

If you wanted salmon to survive on nothing but soya beans, for example, you would have to supplement their diet with missing essential amino acids, such as methionine. More importantly, you would have to find a way to break down phytic acid, the major storage molecule for phosphorus in seeds. Fish don't make phytase, the enzyme that breaks down the acid and allows grazing animals to extract the nutrients from plants. The enzyme can be added to fish feed ${ }^{6}$, but a special heat-stable version - isolated from a fungus gene and produced in bacteria - is required to work efficiently throughout feed processing. It remains to be seen whether this method will be cost-effective.

Plants also contain 'antinutrients' that can be toxic to fish in high concentrations, or that can decrease the fish's ability to absorb minerals from their food. Antinutrients vary from plant to plant and their effects differ for each species of fish, so the diet needs to be carefully tailored for the fish in question. With about 200 species of farmed fish, such

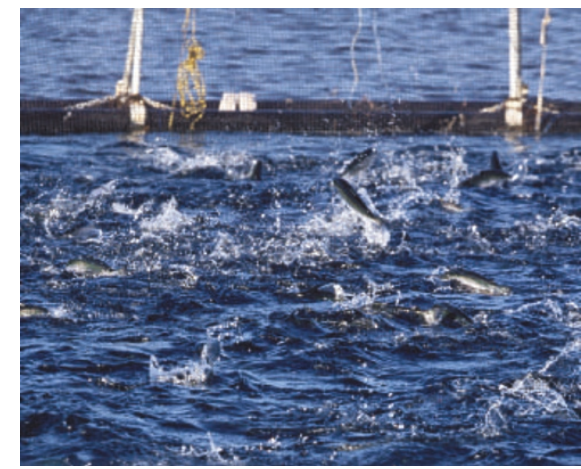

requirements are a financial headache.

Even if you can get fish to eat an all-vegetarian diet, there is the question of whether vegetarian fish taste the same as a carnivorous ones. For better or for worse, using only vegetarian oils in the diet results in milderflavoured, less-oily fish fillets with a different texture. But experts disagree on whether consumers will notice. Abrahamsen says that in taste tests run by Skretting, professional food tasters couldn't tell the difference between salmon raised on vegetarian diets and those raised on traditional carnivorous fare.

\section{Grand designs}

More importantly, vegetarian diets tend to reduce the amount of omega- 3 fatty acids in fish flesh - the compounds that reduce the risk of heart disease in people who eat them. But many feed researchers see this as a challenge rather than a problem. "Just by simple additions to the diet, we can produce a 'designer fish," says Ewen McLean, director of the Virginia Tech Aquaculture Center in Blacksburg. In pilot studies, McLean has added the enzyme lipase, which breaks down fats, to fish diets and has seen an increase in the omega- 3 fatty-acid content of the fish ${ }^{7}$.

Another way to rectify the fat content is to give a fish a vegetarian diet for most of its life, and then follow it with a more 'natural', fishier diet just before going to market. Paul Brown, an aquaculturist at Purdue University in West Lafayette, Indiana, says that just three weeks on such a finishing diet could restore traditional flavours to salmon raised on a vegetarian diet for 18-24 months. Other experts say that a natural diet might be required for two to three months to ensure high levels of omega-3 fatty acids. Even so, that would cut the amount of fish oil used over a fish's life by about $85 \%$.

Many researchers believe that the final hurdles to making vegetarian feed realistic and affordable will be cleared in the next 5-10 years, allowing fish diets to be close to $100 \%$ vegetarian. Three major fish-feed companies - BioMar, Skretting and Ewos, based in Bergen, Norway - have pledged to replace at least $50 \%$ of the fishmeal in their feeds with alternative protein sources by 2010, in addition to finding alternative oil sources.

There are other advantages in store for these farms if they adopt a more vegetarian feed. BioMar, for example, has found that fish fed a diet containing a greater proportion of vegetarian oils tend to excrete less phosphorus and nitrogen in their waste. These are two of the main culprits that cause water pollution in fish farms, as they fertilize algal blooms that can take over ecosystems, using up oxygen and suffocating fish. Researchers working on custom-designing their feed think that these vegetarian diets can be tweaked to optimize this effect, reducing pollution even further.

Large-scale fish farming will still face other obstacles, including problems of escaped fish mating with natural stocks in the wild, and the outbreak of disease in the close quarters of farmed stocks. But if researchers can at least wean carnivorous fish off a diet of wild fish, they will be one step closer to a sustainable industry.

If they succeed, pressures on wild fish stocks won't skyrocket as aquaculture booms. At the same time, the new diet will hopefully reduce pollution, the cost of fish and even world hunger, as at least some of the small fry currently fed to farmed fish could instead be used to feed people. If aquaculture as a whole is to succeed, it needs at the very least to be sustainable - not only for the benefit of wild stocks, but ultimately for the industry and consumers too.

Kendall Powell is a science writer in Broomfield, Colorado.

1. FAO Fisheries Department The State of World Fisheries and

Aquaculture 2002 (FAO, Rome, 2002)

www.fao.org/sof/sofia/index_en.htm

2. Weber, M. What Price Farmed Fish (SeaWeb Aquaculture

Clearinghouse, Providence, RI, 2003);

www.seaweb.org/resources/sac

3. Naylor, R. L. et al. Nature 405, 1017-1024 (2000).

4. International Fishmeal and Fish Oil Organisation Sustainabilit of Fishmeal and Fish Oil Supply presented at the ScottishNorwegian Conference on Sustainable Futures for Marine Fish Farming, June 2001; www.iffo.org.uk/tech/sterling.htm

5. Refstie, S., Storebakken, T., Baeverfjord, G. \& Roem, A. J. Aquaculture 193, 91-106 (2001)

6. McLean, E., Craig, S. R., Goddard, S. J., Al-Oufi, H. S. \& Wille, K. Ribarstvo 60, 15-28 (2002).

7. Samuelsen, T., Isaksen, M. \& McLean, E. Aquaculture 194, 161-171 (2001). 